\title{
Pregnancy and Epilepsy: Monitoring and Treating the Seizures
}

\section{Gebelik ve Epilepsi: Nöbetlerin Takip ve Tedavisi}

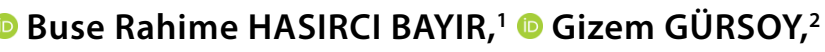 \\ (1) Kemal TUTKAVUL, ${ }^{1}$ (1) Yılmaz ÇETINKAYA ${ }^{1}$
}

\author{
'Department of Neurology, Haydarpaşa Numune Training and Research Hospital, İstanbul, Turkey \\ ${ }^{2}$ Department of Neurology, Hakkari Şemdinli State Hospital, Hakkari, Turkey
}

\section{Summary}

Objectives: Epilepsy is the second most common neurological disorder after migraine in pregnancy. The most suitable antiepileptic drug (AED) to be chosen in this period would minimize the possible maternal and fetal complications. The present study monitors the pregnancies and prognoses of pregnant patients with epilepsy, who were treated in our clinic, and evaluates the efficiency of the antiepileptic treatment.

Methods: In this study, 50 pregnant patients were included who were examined and treated in the epilepsy clinic from January 2000 to May 2018. Seizure types and frequencies, AEDs used, and pregnancy processes of the patients were investigated retrospectively based on their medical file records.

Results: Of the 1965 patients with epilepsy, the number of pregnant patients included in this study was 50 (2.54\%), while the total number of pregnancies was 68 and 27 pregnant patients had generalized onset seizures. There were not any changes in the seizure frequency in $57.1 \%$ of the patients. In this study, 40 patients were treated with monotherapy. The most frequently preferred AED was valproic acid with 10 patients. During the pregnancy, the daily dose was increased for 10 patients, and the drug with the highest increment was lamotrigine with four patients. Considering the births concerning fetal malformation, only one infant had spina bifida, and there were no stillbirths.

Conclusion: This hospital-based study showed that the course of seizure frequency during pregnancy is unpredictable. Following-up and monitoring the pregnant patients closely are of critical importance for pregnant women with epilepsy to have a healthier pregnancy with possible lowest complication rates.

Keywords: Antiepileptic drugs; epilepsy; fetal malformation; pregnancy.

\section{Özet}

Amaç: Epilepsi gebelerde migrenden sonra en sık görülen nörolojik hastalıktır. Bu dönemde seçilecek en uygun antiepileptik ilaç (AEI) ile olası maternal ve fetal komplikasyonlar en aza indirilebilir. Bu çalışmada amacımız, kliniğimizde tedavi edilen epilepsili gebelerin gebeliklik sürecinde prognozlarını ve antiepileptik tedavilerinin etkinliğini değerlendirmektedir.

Gereç ve Yöntem: Bu çalışmaya, Ocak 2000-Mayıs 2018 tarihleri arasında epilepsi kliniğinde muayene ve tedavi edilen 50 gebe hasta dahil edildi. Hastaların nöbet tipleri ve sıklıkları, kullanılan AEl'ler ve gebelik süreçleri, tıbbi dosya kayıtlarına göre geriye dönük olarak incelendi.

Bulgular: Epilepsi hastalığı olan 1965 hasta içinde, çalışmaya dahil edilen gebe hasta sayısı 50 (\%2.54), toplam gebelik sayısı 68 idi. Yirmi yedi hastada (\%54) jeneralize tipte nöbet izlendi. Hastaların \%57.1'inde nöbet sıklığında değişiklik yoktu. Kırk hasta monoterapi ile tedavi edildi. En sık tercih edilen AEI, 10 hasta ile valproik asit oldu. Hamilelik sırasında 10 hastanın günlük ilaç dozu arttııldı ve en fazla doz artışı olan ilaç dört hasta ile lamotrijin idi. Fetal malformasyon açısından değerlendirildiğinde, sadece bir bebekte spina bifida vardı ve ölü doğum yoktu.

Sonuç: Bu hastane tabanlı çalışma, hamilelik sırasında nöbet sıklığının seyrini tahmin etmenin zor olduğunu göstermiştir. Epilepsili hamile kadınların, gebelik sürecini olası en düşük komplikasyon oranlarıyla geçirebilmeleri için, hamile hastaların takibi ve yakından izlenmesi kritik öneme sahiptir.

Anahtar sözcükler: Antiepileptik ilaçlar; epilepsi; fetal malformasyon; gebelik.

(C) 2019 Türk Epilepsi ile Savaş Derneği

(C) 2019 Turkish Epilepsy Society 


\section{Introduction}

Epilepsy is a common neurologic disorder with a prevalence of 5-9/1.000 in developed countries. ${ }^{[1]}$ Causing a lot of obstetric problems, epilepsy during pregnancy is one of the major causes of maternal mortality and morbidity. ${ }^{[2]}$ Since a substantial majority of patients with epilepsy is fertile women, who should be monitored and followed-up closely from the beginning of their planned pregnancy period.

The second most common neurological disorder after migraine in pregnant women is epilepsy. The incidence of epilepsy in pregnant women is $0.3-0.7 \% .{ }^{[2]}$ Seizure frequency in pregnancy may remain unchanged or decreases in two-third of the women with epilepsy, while it may increase in others. ${ }^{[3]}$ Establishing the balance between seizure control and teratogenic risk is one of the main principles of epilepsy treatment in pregnancy. ${ }^{[4]}$ Changes in the pharmacodynamical and pharmacokinetic effects of AEDs used during pregnancy, and the genetic and socioeconomic factors may affect the fetal health adversely. ${ }^{[3]}$ We can reduce the risks of complications during pregnancy by seeing the doctor before getting pregnant in a planned pregnancy scenario, administering and regulating the AED treatment in this process, and starting folic acid. ${ }^{[5]}$

The present study aims to evaluate the efficacy of antiepileptic drugs used during monitoring and the seizure frequencies in pregnant patients diagnosed with epilepsy before pregnancy, who are monitored in our outpatient clinic.

\section{Materials and Methods}

The present study was carried out retrospectively based on the data-on-files belonging to pregnant women monitored for epilepsy in the Epilepsy Outpatient Clinic at the Haydarpaşa Numune Training and Research Hospital Neurology Department. This study included pregnant women with epilepsy taking drugs and monitored from January 2000 to May 2018. Patients under 18 years old and who did not use antiepileptic drugs before pregnancy were excluded from this study. Local Ethics committee approval received from Haydarpaşa Numune Training and Research Hospital.

The present study evaluated the age, seizure and seizure type, duration of epilepsy; the pregnancy-related information, such as seizure frequency before, during and after pregnancy, how many times more the patients had been pregnant before, and the type of labor, the presence of malformation in the infants, and the breastfeeding. This study also investigated whether the pregnancies were planned or not, the use of folic acid during pregnancy, the use, dose and substitution of AEDs in pregnancy, and the presence of status epilepticus in pregnancy.

\section{Statistical analysis}

Statistical analysis was performed with the help of Microsoft Office Excel program. For descriptive analysis, categorical data were expressed as frequency ( $n$ ) and percentage (\%), while continuous data were expressed as mean.

\section{Results}

Of the 1965 patients, a total of 68 pregnant women were identified, of whom 13 were excluded from this study because they had been monitored without medication during pregnancy while five pregnant women were excluded from this study due to incomplete data-on-files. The present study proceeded with 50 patients (2.54\%), who had 68 pregnancies in total. We monitored 34 (68\%) of them in their first pregnancy, 14 in both of their pregnancies, two in all three of their pregnancies. Only 19 (38\%) patients had planned their first pregnancy, while only one patient had planned her next pregnancies.

The mean age was 26.4 years during their first pregnancy. In these patients, the mean age of seizure onset was 14.7, and the mean duration of epilepsy was 11.5 years. Twentythree patients (46\%) described focal seizures, while $27(54 \%)$ of them described generalized seizures. There were no patients whose seizure types changed during pregnancy. Concerning the frequency of seizures, $48 \%$ of the patients had seizures fewer than once a year, $24 \%$ had seizures fewer than once a month, and $28 \%$ had seizures once or more than once a month. Fourteen patients had seizures during pregnancy three of these patients had a single seizure while 11 patients had more than three seizures, which occurred from beginning to end but most frequently (64.3\%) in the 3rd trimester (Table 1). Only one patient developed status epilepticus.

In their first pregnancy monitoring, 40 patients (80\%) were administered monotherapy, while 10 patients received polytherapy. In the monotherapy group, the most commonly preferred active ingredient was valproic acid with 10 patients, which was used in a mean dosage of $770 \mathrm{mg} /$ day (Table 2). In polytherapy patients, the most commonly used 
Table 1. Clinical features of the patients in the first pregnancy monitoring

\begin{tabular}{lll}
\hline & $\mathrm{n}$ & $\%$ \\
\hline Seizure type & & \\
$\quad$ Focal & 23 & 46 \\
$\quad$ Generalized & 27 & 52 \\
$\quad$ & & \\
$\quad$ Seizure frequency & 24 & 48 \\
$\quad$ Less than once a year & 12 & 24 \\
$\quad$ Less than once a month & 14 & 28 \\
$\quad$ Once or more than once a month & & \\
$\quad$ Seizure during pregnancy & 14 & 28 \\
$\quad$ Yes & 36 & 72 \\
$\quad$ No & & \\
Seizure frequency during pregnancy & 4 & 28.6 \\
$\quad$ Increase & 2 & 14.3 \\
$\quad$ Decrease & 8 & 57.1 \\
$\quad$ No change & & \\
Seizure time & 6 & 42.9 \\
$\quad 1^{\text {st }}$ trimester & 6 & 42.9 \\
$2^{\text {nd }}$ trimester & 9 & 64.3 \\
$\quad 3^{\text {rd trimester }}$ & & \\
\hline
\end{tabular}

combinations were carbamazepine + levetiracetam and valproate + lamotrigine with three patients each. There were changes in treatment for nine patients during pregnancy. We substituted polytherapy with monotherapy in four of these patients and ended drug treatment in one patient. We also substituted valproic acid with levetiracetam in two patients and lamotrigine with levetiracetam in one patient, while we substituted monotherapy with polytherapy in one patient by adding lamotrigine to the treatment.

For four patients, the antiepileptic drug dose decreased during their first pregnancy compared to their pre-pregnancy period, whereas there was an increase for the 10 patients. The drug with the highest dose increase was LTG with four patients and its dose increasing from $150 \mathrm{mg} /$ day to 362.5 $\mathrm{mg} /$ day. For three patients, the dose decreased during their second pregnancy monitoring, while it increased for one patient. One patient discontinued antiepileptic drug treatment of her own free will. All the patients started to take folic acid supplements before pregnancy for planned pregnancy cases, and from the time, the patient reported pregnancy for unplanned pregnancy cases, and only one patient discontinued folic acid intake due to gaining weight.

In their first pregnancy monitoring, eight patients gave vaginal birth, while $84 \%$ of the patients underwent cae-
Table 2. Mean dosage and duration of use in monotherapy patients according to active ingredients

\begin{tabular}{lccc}
\hline $\begin{array}{l}\text { Active } \\
\text { ingredient }\end{array}$ & $\begin{array}{c}\text { Number } \\
\text { of } \\
\text { patients }\end{array}$ & $\begin{array}{c}\text { Mean dose } \\
\text { before } \\
\text { pregnancy } \\
\text { (mg/day) }\end{array}$ & $\begin{array}{c}\text { Mean } \\
\text { duration } \\
\text { of use } \\
\text { (years) }\end{array}$ \\
\hline Valproic acid & 10 & 770 & 9.6 \\
Carbamazepine & 9 & 800 & 10.4 \\
Lamotrigine & 9 & 194.4 & 6.3 \\
Levetiracetam & 6 & 1208.3 & 5.5 \\
Oxcarbazepine & 4 & 1112.5 & 8 \\
Phenytoin & 1 & 50 & 11 \\
Topiramate & 1 & 175 & 2 \\
\hline
\end{tabular}

Table 3. Pregnancy follow-up results of the patients

\begin{tabular}{lcc}
\hline & $\mathrm{n}$ & $\%$ \\
\hline Type of childbirth & & \\
$\quad$ Normal vaginal birth & 8 & 16 \\
$\quad$ C-section & 42 & 84 \\
Result of delivery & & \\
$\quad$ Healthy full-term birth & 40 & 80 \\
$\quad$ Stillbirth & 0 & 0 \\
$\quad$ Miscarriage & 4 & 8 \\
$\quad$ Preterm birth & 6 & 12 \\
Malformation & & \\
Yes & 1 & 2 \\
No & 49 & 98 \\
\hline
\end{tabular}

sarean delivery. Four patients had a miscarriage and six gave preterm birth. Four patients had postpartum seizures. Only two patients did not nurse their infants. One infant was diagnosed with spina bifida, and none of the other infants had congenital anomalies (Table 3). During pregnancy monitoring, one patient was diagnosed with oligohydramnios and one other patient was diagnosed with hydronephrosis. Infant monitoring resulted in a diagnosis of epilepsy for one infant, and autism for one other infant.

In the following pregnancy monitoring sessions, only one of 14 pregnant patients had planned her pregnancy. One pregnant woman did not have seizures in her first pregnancy but had seizures in her second pregnancy while the prognoses of the other 13 pregnant patients were not different from the pregnant patients during their first pregnancy. Four patients received an antiepileptic drug treatment different than that in their first pregnancy; there were changes in monotherapy (VPA and LEV) for two patients; LEV-VPA 
substituted the LTG-VPA combination in one patient; and the first pregnancy was monitored administering OXC and the second and third pregnancies were monitored administering the LTG-LEV combination in one patient. One patient had a miscarriage in her second pregnancy, while two patients had preterm births in their second pregnancies.

\section{Discussion}

Given that the course of seizure frequency during pregnancy is unpredictable makes the management of epilepsy challenging. Non-compliance is the first cause of the increase in seizure frequency. Unless the pregnant women have sought counsel or been informed properly and adequately in the preconception period, they may usually discontinue their drug treatment, especially in the first three months of pregnancy, to protect themselves from the probable teratogenic effects the AEDs. Physiological changes in pregnancy may also cause an increase in seizure frequency. The main causes of this include changes in estrogen and progesterone levels during pregnancy, nausea, vomiting, changes in drug serum blood levels associated with hypoalbuminemia, and increased renal clearance. ${ }^{[6]}$ It is estimated that focal seizures affect the fetus less than the generalized seizures, and there is a higher risk of harm for the fetus in cases of loss of consciousness and simultaneous traumas. In generalized seizures, changes in electrolyte levels, blood pressure and oxygen saturation may cause adverse effects on the fetus..$^{[7]} A$ study by Bardy compared seizure frequencies of 154 patients with their pre-pregnancy period and found a decrease in $14 \%$ of the cases, an increase in $32 \%$ of the case, and no change in $23 \%$ of the cases, and $31 \%$ of them were seizure-free ${ }^{[8]}$ In the study by Gjerde et al., ${ }^{[9]}$ when compared with the pre-pregnancy period, the seizure frequencies of 78 patients decreased in $16.7 \%$ of the cases, increased in $16.7 \%$ of the cases, and did not change in $66.6 \%$ of the cases. Our study found no change in $57.1 \%$ of the patients, an increase in $28.6 \%$, and a decrease in $14.3 \%$ of the patients.

A study by EURAP (European and International Registry of Antiepileptic Drugs and Pregnancy) examined 1956 pregnancies of 1882 women with epilepsy. The study found deterioration in the 2 nd and 3rd trimesters in $17.3 \%$ of the cases and convulsive seizures in all three trimesters in $1.8 \%$ of the patients. The monotherapy group included $78.7 \%$ of the patients, while the polytherapy group had $21.3 \%$ of the patients. The study diagnosed 36 of 1956 patients with sta- tus epilepticus (SE) 12 of which were convulsive while 24 were non-convulsive. ${ }^{[10]}$ In our study, 40 patients (80\%) were administered monotherapy while 10 patients were administered polytherapy, and the 3rd trimester was the trimester with the highest frequency of seizures (64.3\%). None of our patients had non-convulsive $S E$, while only one patient had convulsive SE.

The EURAP study concludes that there is a lower likelihood for patients with no seizures until labor to have seizures during or after childbirth. ${ }^{[10]}$ If there are no seizures for nine months before pregnancy, the probability of having no seizures during pregnancy increases. A previous study found out that $94 \%$ of 54 patients with no seizures in nine months before pregnancy and $92 \%$ of 48 patients with no seizures in a year before pregnancy had no seizures during pregnancy. ${ }^{[11]}$ Our study revealed that $78.3 \%$ of the 24 patients with no seizures in at least one year before pregnancy had no seizures during pregnancy.

The review of the data relating to the use of AEDs in pregnancy reveals that VPA is the drug with the highest risk of major congenital malformation (MCM). ${ }^{[12]} A$ total daily dose lower than $800 \mathrm{mg}$ is associated with lower risk, while a dose higher than $1500 \mathrm{mg}$ is associated with higher risk. ${ }^{[13]}$ VPA-associated congenital malformations include neural tube defects, skeletal anomalies, hypospadias, and cleft anomalies. ${ }^{[12]}$ There are findings suggesting that using a combination with a lower dose of VPA instead of monotherapy with a high dose of VPA reduces the risk of congenital malformation. ${ }^{[14]}$ In their study with 3607 pregnant women, Morrow et al. ${ }^{[15]}$ found the MCM absolute risk ratio of $6.2 \%$ for VPA, 3.2\% for LMT, 3.7\% for PHT, and 2.2\% for CBZ. They diagnosed MCM only in $4.2 \%$ of the live births and found a higher ratio in the polytherapy group than in the monotherapy group. Thomas et al. ${ }^{[16]}$ reported that the risk of cardiac malformation was $6.3 \%$ with CBZ. It was shown that the risk of MCM increased by twice to three times in pregnant women using PHT compared to pregnant women who did not use it. ${ }^{[15]}$ In a study, 12 of 414 pregnant patients who were using LTG, which has frequently been used by pregnant women recently, as monotherapy were diagnosed with $M C M$, which is a similar ratio to the ratio in the general public. ${ }^{[17]}$ In their study with pregnant women with epilepsy, Holmes et al. ${ }^{[18]}$ found out the risk of MCM 4.1\% for TPM, and $2.3 \%$ for LEV. In our study, one patient who had been using VPA for three years and got pregnant while using it in a 
dosage of $450 \mathrm{mg} /$ day gave birth to an infant with spina bifida. We did not detect any major or minor congenital malformations in other infants. The lower number of complications in our subjects compared to other mentioned studies could be explained with our small number of cases.

Starting to take folic acid one to three months before pregnancy is possible only if the patient plans her pregnancy beforehand and comes to her visits regularly before getting pregnant. In our study, only 16 patients reported beforehand they had been planning to get pregnant, all of whom started to take prophylactically the recommended folic acid replacement therapy of 4-5 mg/day. Other pregnant patients started the replacement therapy as of the date they reported their pregnancy in the follow-up visits. Using 4 $\mathrm{mg}$ folic acid in the preconception period, and especially in weeks 3 and 8 of the pregnancy, reduces the formation of neural tube by $50 \% .{ }^{[19]}$ We diagnosed spina bifida in only one infant. Although all AEDs pass into the breastmilk in small amounts, the use of these drugs and the presence of epilepsy are not regarded as contraindications for nursing. [20] Therefore, pregnant women should be encouraged to breastfeed their infants. All of our subjects tried to breastfeed except for two mothers who failed because their infants did not nurse.

This study demonstrated that only a minority of our patients had a planned pregnancy both for their first (1 out of 19) and also following (1 out of 14) ones. In the study by Johnson et al., $^{[21]}$ when compared to $48 \%$ in women without epilepsy, $55 \%$ of the pregnancies of the women with epilepsy were unintended. Patients should certainly plan their pregnancies and see a doctor before getting pregnant to reduce the seizure frequency and epileptic complications in pregnancy and regulate and adjust their AED treatments. Patients should take AEDs in divided and the lowest doses possible and should try to replace polytherapy with monotherapy. Mothers using AEDs have a higher risk of underdeveloped infants, prematurity, miscarriage, and major malformation than those who do not use AEDs. ${ }^{[22]}$ The study by Tantik Pak et al. ${ }^{[23]}$ with 55 pregnant women diagnosed with epilepsy found out that the ratios of stillbirth and malformation were higher in the polytherapy group than in the monotherapy group. In this study, we changed the treatment regimens of nine subjects, from polytherapy to monotherapy in four patients, and discontinued the medication for one subject. We also substituted monotherapy with polytherapy only in one patient by adding LTG to the LEV therapy due to the increased frequency of generalized seizures in the $2^{\text {nd }}$ and $3^{\text {rd }}$ trimesters. In our study, there were no pregnant women with intrauterine fetal death, four women miscarried, and six women had a preterm birth.

There are no risks for pregnant women with epilepsy to have a normal vaginal birth. However, labor is a period with a risk of seizure during which the seizure frequency increases by nine times. ${ }^{[8]}$ If the patient has an increased seizure frequency, and the seizures are resistant to treatment in the final phase of the pregnancy, caesarean delivery should be preferred. ${ }^{[24]} 86 \%$ of our subjects had a caesarean delivery. In the postpartum period, lack of sleep and changes in daily life brought by the birth of the infant pose a risk for seizure frequency. We detected postpartum seizures only in four patients who gave birth with caesarean delivery. One of these patients had generalized seizures in each trimester, and more than three generalized seizures in total, while the other three patients had no seizures during their pregnancies.

The limitations of this study are the retrospective design and the number of cases. Further multi-centered and longer studies may enable safer monitoring and follow-up for patients during pregnancy.

As a result, the course of the seizure frequency during pregnancy is unpredictable. Although the frequency of seizures in pregnant women with epilepsy may occur in every period of pregnancy, many researchers agree that they often occur in the last trimester. Not to suffer from unfavorable results during and after pregnancy, fertile women with epilepsy should plan their pregnancies beforehand. Following-up and monitoring the pregnant patients closely are of critical importance for pregnant women with epilepsy to have a healthier pregnancy without complications.

\section{Acknowledgment}

We thank Abdullah Karaakın for translating this study from Turkish into English.

\section{Ethics Committee Approval}

Ethics committee approved.

\section{Peer-review}

Externally peer-reviewed.

\section{Conflict of interest}

The authors declare that they have no conflict of interest. 


\section{Authorship Contributions}

Concept: B.R.H.B.; Design: B.R.H.B., G.G.; Supervision: K.T., Y.Ç.; Materials: B.R.H.B., K.T., Y.Ç.; Data collection \&/or processing: B.R.H.B.; Analysis and/or interpretation: B.R.H.B., G.G.; Literature search: B.R.H.B.; Writing: B.R.H.B., G.G.; Critical review: K.T., Y.Ç.

\section{References}

1. Kwan P, Brodie MJ. Early identification of refractory epilepsy. N Engl J Med 2000;342(5):314-9. [CrossRef]

2. Edey S, Moran N, Nashef L. SUDEP and epilepsy-related mortality in pregnancy. Epilepsia 2014;55(7):72-4. [CrossRef]

3. Thomas SV. Management of epilepsy and pregnancy. J Postgrad Med 2006;52(1):57-64.

4. Tomson T, Landmark CJ, Battino D. Antiepileptic drug treatment in pregnancy: changes in drug disposition and their clinical implications. Epilepsia 2013;54(3):405-14. [CrossRef]

5. Crawfort P. Best practice guidelines for the management of women with epilepsy. Epilepsia 2005;46(9):117-24. [CrossRef]

6. Yerby MS. Pregnancy and epilepsy. Epilepsia 1991;32(6):51-9.

7. Sveberg L, Svalheim S, Taubøll E. The impact of seizures on pregnancy and delivery. Seizure 2015;28:35-8. [CrossRef]

8. Bardy $\mathrm{AH}$. Incidence of seizures during pregnancy, labor and puerperium in epileptic women: a prospective study. Acta Neurol Scand 1987;75:356-60. [CrossRef]

9. Gjerde IO, Strandjord RE, Ulstein M. The course of epilepsy during pregnancy: a study of 78 cases. ActaNeurol Scand 1988;78(3):198-205. [CrossRef]

10. EURAP Study Group. Seizure control and treatment in pregnancy: observations from the EURAP epilepsy pregnancy registry. Neurology 2006;66(3):354-60. [CrossRef]

11. Tanganelli P, Regesta G. Epilepsy, pregnancy, and major birth anomalies: an Italian prospective, controlled study. Neurology 1992;42(4-5):89-93.

12. Campbell E, Kennedy F, Russell A, Smithson WH, Parsons L, Morrison PJ, et al. Malformation risks of antiepileptic drug monotherapies in pregnancy: updated results from the UK and Ireland Epilepsy and Pregnancy Registers. J Neurol Neurosurg Psychiatry 2014;85(9):1029-34. [CrossRef]
13. Tomson T, Battino D, Bonizzoni E, Craig J, Lindhout D, Sabers A, et al. Dose-dependent risk of malformations with antiepileptic drugs: an analysis of data from the EURAP epilepsy and pregnancy registry. Lancet Neurol 2011;10(7):609-17. [CrossRef]

14. Tomson T, Battino D, Bonizzoni E, Craig J, Lindhout D, Perucca $E$, et al. Dose-dependent teratogenicity of valproate in mono- and polytherapy: an observational study. Neurology 2015;85(10):866-72. [CrossRef]

15. Morrow J, Russell A, Guthrie E, Parsons L, Robertson I, Waddell $\mathrm{R}$, et al. Malformation risks of antiepileptic drugs in pregnancy: a prospective study from the UK Epilepsy and Pregnancy Register. J Neurol Neurosurg Psychiatry 2006;77(2):193-8. [CrossRef]

16. Thomas SV, Ajaykumar B, Sindhu K, Francis E, Namboodiri N, Sivasankaran $\mathrm{S}$, et al. Cardiac malformations are increased in infants of mothers with epilepsy. Pediatr Cardiol 2008;29(3):604-8.

17. Cunnington M, Tennis P. International Lamotrigine Pregnancy Registry Scientific Advisory Committee. Lamotrigine and the risk of malformations in pregnancy. Neurology 2005;64(6):95560. [CrossRef]

18. Holmes LB, Smith CR, Hernandez-Diaz S. Pregnancy registries; larger samples sizes essential: 48th Annual Meeting of the Teratology Society; Birth Defects Research (Part B). Proceedings of the 48th annual meeting of the teratology society; 2008. p. 307.

19. Medical Research Council Vitamin Study Researcg Group. Preventation of neural tube defects: results of the MRC vitamin study. Lancet 1991;338(8760):131-7. [CrossRef]

20. Sabers $A$, Tomson T. Managing antiepileptic drugs during pregnancy and lactation. Curr Opin Neurol 2009; 22(2):157-61.

21. Johnson EL, Burke AE, Wang A, Pennell PB. Unintended pregnancy, prenatal care, newborn outcomes, and breastfeeding in women with epilepsy. Neurology 2018;91(11):e1031-9. [CrossRef]

22. Thomson T. How should be epilepsy treated in pregnancy? ILAE Commision on Therapeutic Strategies. ILAE Annual Report 2004:28-30.

23. Tantik Pak A, Bozdemir H, Aslan K, Peköz T, Ünal İ, Büyükkurt S. Maternal and obstetric outcome of women with epilepsy. Turkiye Klinikleri J Neur 2017;12(3):64-70. [CrossRef]

24. Steinhoff BJ. Pregnancy, epilepsy, and anticonvulsants. Dialogues Clin Neurosci 2008;10(1):63-75. 